\title{
The analysis of developing the "three ones" professional English didactics of Computer Science and Technology of civilian-run Applied University
}

\author{
Xuehang Shao, Ying Yang, Xiao-feng Li \\ Department of Computer Science and Technology, \\ ChengDong College of Northeast Agricultural University \\ Harbin, 150025,China \\ 46176838 @qq.com
}

\begin{abstract}
This article mainly aims at the problems facing the teaching situation of professional English of Computer Science and Technology of civilian-run Applied University, proposed the "three ones" professional English teaching method, and detailed its implementation process and feasibility.
\end{abstract}

Keywords-component;Applied;Three ones;Teaching method

\section{INTRODUCTION}

The core of the era is information technology which has penetrated into every aspects of people's life and work. For the new theory and the new technology about computer coming from abroad mostly, as a unifying language of computer and IT industries, English is irreplaceable by other languages[1-2]. Therefore, people who study the latest computer technology should be mastery of and proficient in applying computer professional English. Since the Chinese Ministry of Education emphasizes the need of training applied talents and the philosophy of teaching that strives to make students possess "a solid theoretical foundation and rich experience, strong learning ability, quickly working ability and high quality " of our department, the place of computer professional English is also becoming more special and important. Based on this, many Private Applied University make computer professional English become a professional required course of Computer science and technology major students, and it takes a very important position in computer professional teaching[3].

The computer professional English is a basic skills which involves the extension of professional knowledge of the students majoring in computer science, thus studying the computer professional English with regard to the students of Private Applied University is of vital importance[4].

\section{THE TEACHING SITUATION OF COMPUTER PROFESSIONAL ENGLISH}

\section{A. Students have poor basis, and lack of study enthusiasm}

Most of students' English of civilian-run applied universities foundation is relatively poor, and low interest in English. Most of the computer professional English teaching materials are argumentation and exposition, in which vocabulary, abbreviation, long sentences are in the majority. This lead to that the students who are lack of learning motivation stay a respectful distance to professional English..

\section{B. The teaching material is relatively backward}

Currently, the versions of domestic computer English teaching materials look scarce, in which the content are as a comprehensive introduction to computer basic knowledge, and some theoretical knowledge seem to be partial difficult, serious short of practice, not suitable for civilian-run applied college students using. The specialized word is overmuch in the essay also interfere with the students' understanding. Today, with the rapid development of computer technology, although computer software and hardware develops quite fast, most of the materials have serious lag. New products, new words emerging in endlessly, how to let the computer professional English teaching material retain freshness, keeping up with the development of the Times step is particularly important.

\section{The teaching process is not in line with the teaching Objectives}

The computer professional English is computer science and technology's major compulsory course of civilian-run applied universities, which teaching goal is: demand the students master their current speciality's the basic vocabulary and new words in common use; can read,comprehend and translate English professional articles in cyber domains, as well as sum up the purport of the reading paper and seize important details and relevant data; in addition, could be preliminary equipped with ability to use English for communication. But now many university of applied run by the local continue traditional English teaching as before that simply converted the learning of computer professional English into memorizing specialized word and translating professional articles. Through lecturing words words and translation tips along with requiring students to do exercises to complete teaching, hence the teaching process is fairly homogeneous,it is difficult to reach the expected teaching goal[5].

\section{With strong professional}

Compared with Basic English, there are a large amount of specialized vocabulary and terms, with many of the 
conventional phraseology. But most originate from common everyday words, take its old fashioned definition, and are endowed with proprietary meaning of similar functions In the field of computer as well. For instance: memory, instruction, code, program, cache, etc[6].

\section{PROBLEMS WITH THE COMPUTER PROFESSIONAL ENGLISH TEACHING}

\section{A. Teaching methods and teaching forms}

Present specialized English for computer classroom teaching more for the traditional teaching mode that centers on teachers as usual.The teaching fall broadly into: learning new word-analysising of the point and difficult sentences_— translating article_-finishing homework assignments, in which the teacher process absolute predominance, students are difficult to have independent play space. For a period of time in the same teaching mode, easy to make students form the thinking set, students with a good basis consider that it would be sufficient if they could read themselves and follow in class the teacher's translation to learn this course, no need to take any extra-curricular time; while students with poor foundation are even more feel boring, losing interest in learning.

\section{B. The aspect of teachers}

Because of the particularity of computer English courses, the instructors must have a solid foundation in English and computer professional knowledge base, this will make choose teacher more difficulty. Although English teachers have a higher English teaching ability, but due to lacking of calculator professional knowledge, The course will be taught as public English teaching, focusing on the vocabulary and grammar, difficult to highlight the characteristics of computer major; by contrast,computer teachers could explain and guide well in special knowledge, but suffer for English proficiency in teaching this course, , difficult to implement the bilingual teaching.

\section{The aspect of students}

The students of civilian-run universities applied have no interest in learning English on account of weak foundation in secondary school. Additionally, computer English textbooks mostly are exposition and argumentation, in which have numerous vocabulary, abbreviation, long and also difficult sentences, require the students to find a large number of information, analysis the sentence, understand the text in patience, that is likely to make students afraid of learning computer English easily.

\section{CARRY OUT THE “THREE ONES” PROFESSIONAL ENGLISH DIDACTICS}

Based on the facing situation and basic issues of civilian-run universities above, computer professional English is an vital instrumental course, it aims at cultivating students' professional reading habit, so as to digest the matters in theory and practice in English. In order to improve the students' foreign language proficiency on the discipline and train the high-quality practical talents who has innovation consciousness and practice ability, by careeroriented, the teaching activities of "three ones" professional English didactics in computer science and technology professionals is launched.

\section{A. The definition of "three ones"}

In the teaching processes amongst each specialized course, practice the "three ones" professional English didactics which means a word each class, a sentence each week and a short essay each semester.

\section{B. The specific measures of the "three ones" professional English didactics}

1)Professional teachers organize and edit English words appear in the course, and then lecture one or two meanings, usage, and situated context of special significance to students each class.

2)Professional teachers teach a prepared sentence related with the specialized courses to the class a week.

3)Professional teachers instruct a prepared short essay professional courses relevant to students or submit a tractate concerning learning gains about this course per term.

4)Ask for the students write down major English words, sentences and passages learned in the first two pages of this course's lecture notes.

5)Take specialty English what they learned as part of the result of the academic courses (Note: the division of proportion according to the actual situation of school).

\section{Feasibility analysis}

1)The feasibility of the teachers

The computer system of the computer specialty used an English representation, and that young teachers all have a good English foundation, often use the words and sentences of the course, so if only the teacher collects the words, and then with two or three minutes explain to students, will not affect the normal classroom teaching. Moreover, the teacher does not increase a lot of work.

2)The feasibility of the students

When the computer specialized student participate in computer experiment and training, use English words emerged in professional course quite often, and the computer system that is used shows in English, therefore, in the learning process, students won't feel a lot of pressure in time of studying one or two English words each class. 


\section{The actual teaching effect}

The specialty is divided according to professional foundations, major, professional direction, professional posts, practice and training courses. Using the teaching effect of computer professional (e.g. Software) as an example, after the systematic learning, students could master the computer's common English words, sentences as well as essays, which will play a very big part in improving the students' ability of computer English. Shown in Table 1

In conclusion, the "three ones" professional English didactics is feasible. Make English learning throughout each professional lesson, achieve the English study continuously. Form the study atmosphere that is learning English every lesson, and using English all the time.

\section{E. The teaching effect is expected to reach}

The number of major course adds up to thirty that consist of specialized fundamental course, specialized course, as well as specialized elective course, if each course the student could learn 50 English words on average, they can ultimately learn 1500 words; each course could learn 12 sentences, could learn 600 sentences finally; each course could learn one passage, and could learn thirty essays in the end. Thus when performing learning, students can master all of the common English words specialized, which have a greater role for improving the students' English ability.

\section{CONCLUSION}

In short, the computer English teaching should not let students learn by rote, but combine with the characteristics of computer professional knowledge. Gradually training the ability of computer professional English's application, solving practical issue while learning computer specialized curriculum. Such as try seeing the English prompts while operating computers, try using the English version of the software or interpreting computer English literature, etc. By means of the "three ones" professional English didactics, continually accumulating professional English vocabulary, meaning and special significance, contribute to help different levels increase enthusiasm of learning with different target, mining their learning potential. By learning the professional English involved in the subject for accumulating learning, rather than to further boost the level of professional English, it is possible to enrich students' professional knowledge and improve their overall quality as well.

With the constant development of information technology, computer professional English become increasingly prominent. As a consequence of this, the emphasis of this course should be strengthened by the civilian-run applied university. Teachers should constantly improve the teaching contents and teaching methods in accordance with the principle of their aptitude and the social requirement, in order to enhance the students' practical ability of English, so as to achieve the goal of applicationoriented and technology-oriented talent cultivating.

\section{REFERENCES}

[1] LIU Dan-feng. Application of Case-study Method in English Teaching Methodolog. Journal of Tongren University,2011, pp.6873

[2] WANG Wan-hua. Discussion on English Language Skills Course Reform and Innovative Talents Training. Journal of Hunan Financial and Economic College,2012, pp.112-120.

[3] JIANG Wen-juan. Suggestions on How to Improve Students ' Professional English Proficiency. The Science Education Article Collects,2011, pp.11-21

[4] HAN Jin. On the Amalgamation of Basic English with English for Special Purpose in College English Teaching. Journal of Huangshi Institute of Technology(Humanities and Social Sciences) ,2011, pp.133-141

[5] WU Jun-fang . Application of Course Method in English Teaching Methodolog . Northern Lierature,2012, pp.51-60

[6] LI Min-gang . Professional English in the college English teaching · Journal of Qiqihar university of medicine,2011, pp.78-90

TABLE1 The statistics on teaching effects of the "three ones” professional English didactics of computer specialty

\begin{tabular}{|c|c|c|c|c|c|c|}
\hline $\begin{array}{l}\text { Course } \\
\text { Category }\end{array}$ & Number & Course Name & Period Division & $\begin{array}{l}\text { Vocabulary } \\
\text { (Unit: a) }\end{array}$ & $\begin{array}{l}\text { Sentences } \\
\text { (Unit: a) }\end{array}$ & $\begin{array}{l}\text { Essay } \\
\text { (Unit: } \\
\text { piece) }\end{array}$ \\
\hline $\begin{array}{c}\text { Specialized } \\
\text { basic } \\
\text { course } \\
\end{array}$ & 1 & Computer Basis & 56 & 56 & $\begin{array}{c}14(4 \\
\text { hours/week })\end{array}$ & 1 \\
\hline \multirow{5}{*}{$\frac{\text { Specialized }}{\underline{\text { course }}}$} & 2 & C Language Programming & 70 & 70 & $\begin{array}{l}14 \text { ( } 5 \text { hours/ } \\
\text { week) }\end{array}$ & 1 \\
\hline & 3 & Data Structure & 68 & 68 & $\begin{array}{c}17(4 \\
\text { hours/week }) \\
\end{array}$ & 1 \\
\hline & 4 & $\begin{array}{l}\text { SQL Server Management } \\
\text { and Query }\end{array}$ & 32 & 32 & $\begin{array}{c}8(4 \\
\text { hours/week })\end{array}$ & 1 \\
\hline & 5 & $\begin{array}{l}\text { Database System and } \\
\text { SQLServer Application }\end{array}$ & 80 & 80 & $\begin{array}{l}16 \text { ( } 5 \text { hours/ } \\
\text { week) }\end{array}$ & 1 \\
\hline & 6 & Computer Network & 68 & 68 & $17(4$ & 1 \\
\hline
\end{tabular}




\begin{tabular}{|c|c|c|c|c|c|c|}
\hline & & & & & hours/week) & \\
\hline & 7 & $\begin{array}{c}\text { Computer Organization } \\
\text { Principles }\end{array}$ & 68 & 68 & $\begin{array}{c}17(4 \\
\text { hours/week) }\end{array}$ & 1 \\
\hline & 8 & Operating System & 68 & 68 & $\begin{array}{c}17(4 \\
\text { hours/week })\end{array}$ & 1 \\
\hline \multirow{6}{*}{$\begin{array}{l}\text { Speciality } \\
\text { orientation } \\
\text { course }\end{array}$} & 9 & $\begin{array}{c}\text { Java Technology and } \\
\text { Application }\end{array}$ & 68 & 68 & $\begin{array}{c}17(4 \\
\text { hours/week })\end{array}$ & 1 \\
\hline & 10 & $\begin{array}{l}\text { Assembly language and } \\
\text { interface technology }\end{array}$ & 82 & 82 & $\begin{array}{c}14(6 \\
\text { hours/week })\end{array}$ & 1 \\
\hline & 11 & Software Engineering & 64 & 64 & $\begin{array}{c}16(4 \\
\text { hours/week })\end{array}$ & 1 \\
\hline & 12 & $\begin{array}{c}\text { Computer assembly and } \\
\text { maintenance }\end{array}$ & 32 & 32 & $\begin{array}{c}8(4 \\
\text { hours/week })\end{array}$ & 1 \\
\hline & 13 & Web Programming & 68 & 68 & $\begin{array}{l}17 \text { ( } 4 \text { hours/ } \\
\text { week) }\end{array}$ & 1 \\
\hline & 14 & Compiler Principle & 64 & 64 & $\begin{array}{l}16 \text { ( } 4 \text { hours/ } \\
\text { week) }\end{array}$ & 1 \\
\hline \multirow{9}{*}{$\begin{array}{l}\text { Professional } \\
\text { posts } \\
\text { course }\end{array}$} & 15 & $\begin{array}{c}\text { MVC Application } \\
\text { Development Foundation }\end{array}$ & 70 & 70 & $\begin{array}{c}14(5 \\
\text { hours/week })\end{array}$ & 1 \\
\hline & 16 & ORACLE Application & 68 & 68 & $\begin{array}{c}17(4 \\
\text { hours/week }) \\
\end{array}$ & 1 \\
\hline & 17 & J2EE frame technology & 80 & 80 & $\begin{array}{c}16 \text { ( } 5 \text { hours/ } \\
\text { week) }\end{array}$ & 1 \\
\hline & 18 & $\begin{array}{l}\text { The.net platform and C\# } \\
\text { programming }\end{array}$ & 68 & 68 & $\begin{array}{l}17 \text { ( } 4 \text { hours/ } \\
\text { week) }\end{array}$ & 1 \\
\hline & 19 & $\begin{array}{c}\text { Use ASP.Net technology } \\
\text { development site }\end{array}$ & 80 & 80 & $\begin{array}{l}16 \text { ( } 5 \text { hours/ } \\
\text { week) }\end{array}$ & 1 \\
\hline & 20 & Cryptology & 34 & 34 & $\begin{array}{c}9(4 \\
\text { hours/week })\end{array}$ & 1 \\
\hline & 21 & $\begin{array}{c}\text { Computer Security } \\
\text { Technology }\end{array}$ & 34 & 34 & $\begin{array}{l}9 \text { (4 hours/ } \\
\text { week) }\end{array}$ & 1 \\
\hline & 22 & $\begin{array}{c}\text { Principle and technology of } \\
\text { firewall }\end{array}$ & 50 & 50 & $\begin{array}{c}13(4 \\
\text { hours/week })\end{array}$ & 1 \\
\hline & 23 & $\begin{array}{c}\text { Intrusion Detection } \\
\text { Technology } \\
\end{array}$ & 30 & 30 & $\begin{array}{c}7(4 \\
\text { hours/week })\end{array}$ & 1 \\
\hline \multirow{4}{*}{$\begin{array}{l}\text { practice } \\
\text { and } \\
\text { training } \\
\text { courses }\end{array}$} & 24 & $\begin{array}{l}\text { C/S model software design } \\
\text { project practice }\end{array}$ & $\begin{array}{c}1 \text { week } \\
\text { (40 hours/week) }\end{array}$ & 40 & 5 & 1 \\
\hline & 25 & $\begin{array}{c}\mathrm{B} / \mathrm{S} \text { model software design } \\
\text { project practice }\end{array}$ & $\begin{array}{c}1 \text { 周 } \\
\text { (40 hours/week) }\end{array}$ & 40 & 5 & 1 \\
\hline & 26 & $\begin{array}{l}\text { Java software engineering } \\
\text { integrated project practice }\end{array}$ & $\begin{array}{c}17 \text { week } \\
\text { (40 hours/week) }\end{array}$ & \multirow{2}{*}{$\begin{array}{l}680 \text { (choose } \\
\text { one of two } \\
\text { directions) }\end{array}$} & \multirow[b]{2}{*}{85} & \multirow[b]{2}{*}{17} \\
\hline & 27 & $\begin{array}{c}\text {.NET software engineering } \\
\text { integrated } \\
\text { project practice }\end{array}$ & $\begin{array}{c}17 \text { week } \\
\text { (40 hours/week) }\end{array}$ & & & \\
\hline Total & \multicolumn{3}{|c|}{27 courses } & 2162 & 421 & 42 \\
\hline
\end{tabular}

